\title{
THE IMPORTANCE OF ENTREPRENEURSHIP FOR WEALTH CONCENTRATION AND MOBILITY
}

\author{
BY VINCENZO QUADRINI
}

Duke University

\begin{abstract}
The paper conducts an empirical analysis of the importance of entrepreneurship for wealth concentration and mobility using data from the Panel Study of Income Dynamics. The data shows a marked concentration of wealth in the hands of entrepreneurs which is not merely a consequence of their higher incomes. The higher saving rates among entrepreneurs is one of the possible explanations for their higher asset holdings and this hypothesis is supported by the statistical tests conducted in the paper. The data also shows that entrepreneurs experience greater upward mobility in that they have a greater probability of moving to higher wealth classes, and this is not only a consequence of their higher incomes.
\end{abstract}

\section{INTRODUCTION}

As is well known, household wealth is highly concentrated, even more concentrated than income. For example Wolff (1995), using data from the Survey of Consumer Finances, reports that in 1989 the top one percent of households owned 39 percent of total wealth. Yet the reason why some families-those at the top of the distribution-accumulate such a high level of wealth is at present unknown and it constitutes a puzzle that a large class of calibrated models is not able to capture as discussed in Quadrini and Ríos-Rull (1997). The question addressed in this paper is whether entrepreneurship plays an important role in generating such a high concentration of wealth.

Using data from the Panel Study of Income Dynamics, the paper documents the main differences in asset holdings and wealth mobility between entrepreneurs and workers, where "entrepreneurs" are defined as families owning their own business and "workers" are defined as all other families. The data analysis shows that there is a marked concentration of wealth in the hands of entrepreneurs and that entrepreneurs experience greater upward mobility than workers. These differences in asset holdings and mobility are not merely accounted for by higher entrepreneurial incomes, as entrepreneurs have higher wealth-income ratios than workers, and they experience greater upward mobility in the wealth-income ratio as well.

The fact that business families own more wealth has been interpreted as evidence of the existence of borrowing constraints: that is, the ownership of a business can only in part be financed with external funds, and therefore, only

Note: I would like to thank Hilary Appel, Thomas Cooley, Michael Greenacre, Boyan Jovanovic, Per Krusell, José-Víctor Ríos-Rull and Kenneth Wolpin for helpful suggestions on earlier versions of this paper. I am also grateful to an anonymous referee whose suggestions have improved the paper considerably. Any errors in this paper are, of course, entirely my own. 
those having enough wealth are in the position to start a profitable business. ${ }^{1}$ According to this interpretation, there is a causal link between the endowment of wealth and the entrepreneurial choice. However, an inverse causation can also be hypothesized: business families own more wealth because they save more. There are several factors, which may account for this. For instance, the presence of liquidity constraints may induce those families with higher entrepreneurial ability to accumulate the capital required to start a business. Another reason may stem from the fact that agents are risk averse and, in order to face the entrepreneurial risk, they accumulate more assets. Finally, the higher saving rate of business families may be a consequence of intermediation costs that make external financing more expensive; thereby implying that entrepreneurs with a lower level of wealth have a higher marginal return from saving. In other words, while it is possible that the presence of liquidity constraints has the effect of selecting entrepreneurs among richer families, it is equally plausible that these families have higher levels of wealth relative to income, because their members have more incentives to save.

If business families were to own more wealth only because they were selected among richer families, then entrepreneurship would not have any implications for wealth inequality, being the inequality in asset holdings that discriminates between workers and entrepreneurs and not vice-versa. In other words, entrepreneurship has positive implications for wealth concentration-in addition to the concentration induced by higher asset holdings as a consequence of higher business incomes-only if entrepreneurs accumulate more wealth than workers. In order to exploit this possibility, I estimate a dynamic accumulation equation on a sample of U.S. families, and I test the hypothesis that workers and entrepreneurs have different saving behaviors. The result of this test supports the hypothesis that enterprising households have a higher targeted wealth-income ratio than workers, and therefore, higher saving rates.

By looking at the "accumulation" of wealth, rather than at its "holding," the analysis is shifted from the static aspects of the wealth distribution to its dynamics, namely, the movement of the agents inside the distribution or socioeconomic mobility. There are several empirical studies analyzing income and earnings mobility. Some studies document intergenerational mobility, such as Behrman and Taubman (1990), Solon (1992) and Zimmerman (1992); while others concentrate on the mobility of the same individual or family, notably Duncan and Morgan (1984), Sawhill and Condon (1992) and Hungerford (1993). These studies, however, do not distinguish among different types of individuals or households and do not extend the analysis to the study of mobility within wealth classes, other than income and earnings. In contrast, this study is primarily interested in analyzing the mobility properties experienced by different economic agents within one generation -namely enterprising households as compared to other households - where the position in the social ladder is identified with wealth.

\footnotetext{
${ }^{1}$ See, for example, Evans and Jovanovic (1989), Evans and Leighton (1989) and Holtz-Eakin et al. (1994). Another interpretation is based on the selection mechanism through which only successful entrepreneurs survive and we only observe the upper tail of the distribution.
} 
In the data analysis of Section 2, I show that enterprising households experience greater upward-mobility than other households, that is, they face greater probabilities of moving to a higher wealth class. Moreover, this upward mobility is not merely a consequence of their higher incomes, since enterprising households also experience greater upward mobility in the ratio of wealth to income as well. This wealth mobility property is consistent with the observation of higher asset holdings of entrepreneurs in the sense that entrepreneurs own more wealth because they tend to move to higher positions in the distribution of wealth. At the same time, the higher upward mobility of entrepreneurs can be interpreted as evidence of the hypothesis that their higher asset holdings is not only a consequence of borrowing constraints that select entrepreneurs among richer familiesas pointed out by Evans and Jovanovic (1989) — but also a consequence of their higher rates of savings.

The different saving patterns of workers and entrepreneurs generate higher asset holdings in the hands of the latter and, as a result, a higher concentration in the whole distribution of wealth. A relevant factor that determines the importance of this mechanism in generating wealth concentration, is the persistence and turnover of households in the business group. Accepting the hypothesis that entrepreneurs save more, the amount of wealth accumulated depends on the business duration, that is the time spent owning a business. Therefore, in Section 4, I analyze the persistence and turnover of households in the business group and I show that despite the high exit rates from entrepreneurship, the turnover rate in the business group is low and a limited percentage of households tend to alternate in the position of entrepreneur. The finding is confirmed by the estimation of a probit model for entrance and exit to and from entrepreneurship. This low turnover allows a restricted group of households to accumulate consistent amounts of wealth (due to their higher saving rates) which in turn generates higher concentration of wealth.

\section{Entrepreneurship and Wealth Concentration}

The main source of data comes from the Panel Study of Income Dynamics (henceforth PSID) which is a national survey conducted annually on a sample of U.S. families since 1968. The original sample included 4,800 families. Over time the sample composition has changed due to the addition of new family units, descending from the previous ones, and the removal of others. Although the survey was taken annually, the main variable of interest for this study-family wealth-is available for only a few years and the main analysis is based upon the 1984 and 1989 wealth data. ${ }^{2,3}$ Accordingly, the sample analyzed in this and the next sections consists of families interviewed in all years from 1984 through 1990 and headed by the same person. ${ }^{4}$

"Family wealth" is defined as the sum of net worths of all family members and results from the aggregation of the following components: house (main home), other real estate, vehicles, farms and businesses, stocks, cash accounts and other assets.

${ }^{3}$ Although wealth data for the 1994 is also available, the paper does not extend the analysis to the 1994 year because other variables which are needed for the analysis are not currently available.

${ }^{4}$ The requirement that the family is headed by the same person is a way of identifying the same family over time, and to link single years data. This link is crucial for the analysis conducted in Sections 2-4. 
The first step of this analysis is to identify business families or entrepreneurs. I adopt two criteria. According to the first criterion, entrepreneurs are families that own a business or have a financial interest in some business enterprise and workers are identified as all other families. ${ }^{5}$ In the second criterion, entrepreneurs are identified as families in which the head is self-employed, in his or her main job, while workers are identified as families in which the head is a dependent worker. ${ }^{6}$ Implicit in the second definition of entrepreneurs is the exclusion from the analysis of those families in which the head is not an active worker. Henceforth, I will call "business owners" enterprising families identified using the first definition of entrepreneurs, and "self-employed" enterprising families identified using the second definition of entrepreneurs.

Figure 1 reports the fraction of business families in different wealth classes, and for the two definitions of entrepreneurs, with each class including five percent of all families. Given the similarity of the 1984 and 1989 data, this graph and the main analysis of the remaining part of this section are based on the average of these two years. Figure 1 shows that business families tend to be concentrated in the higher wealth classes and more than half of the families located in the top class are business families.

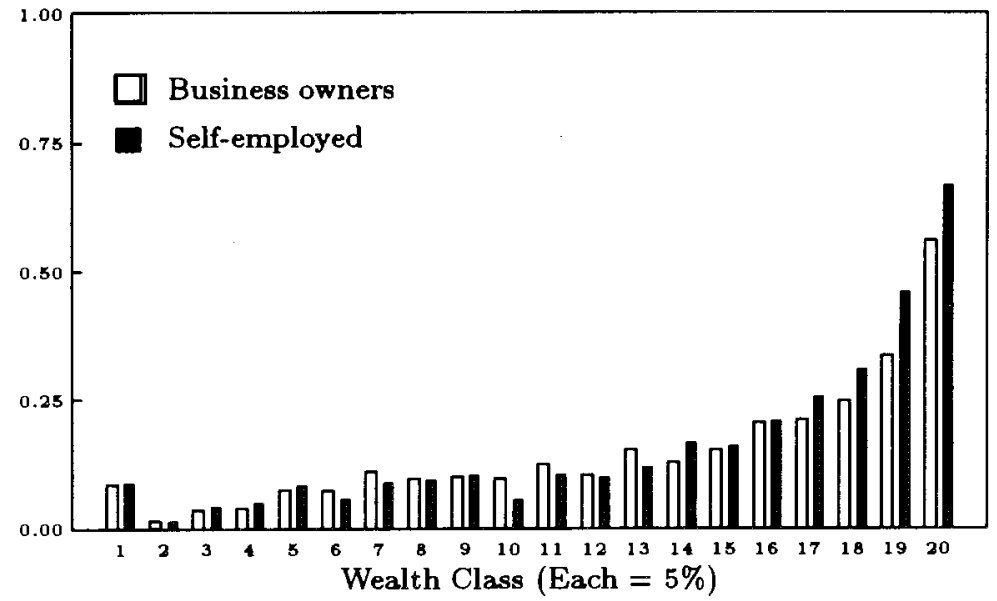

Figure 1. Fraction of Business Families in Each Wealth Class as Average of 1984 and 1989 PSID Data

The fact that business families own more wealth than worker families would not be of particular interest if business families also earn more income (in proportion to the ownership of wealth) and a better evaluation requires the analysis of the joint distribution of income and wealth among these two categories of families. Based on this consideration, Figure 2 reports the average per-family wealth of worker and business families located in each income decile, as a fraction

${ }^{5}$ The identification of enterprising families is based on the PSID variable "Whether Business" which is based on the following interview question: "Did you (Head) or anyone else in the family own a business at any time during the previous year or have a financial interest in any business enterprise?"

${ }^{6}$ The classification is based on the following PSID interview question: "In your main job, are you (Head) self-employed or do you work for someone else?" 

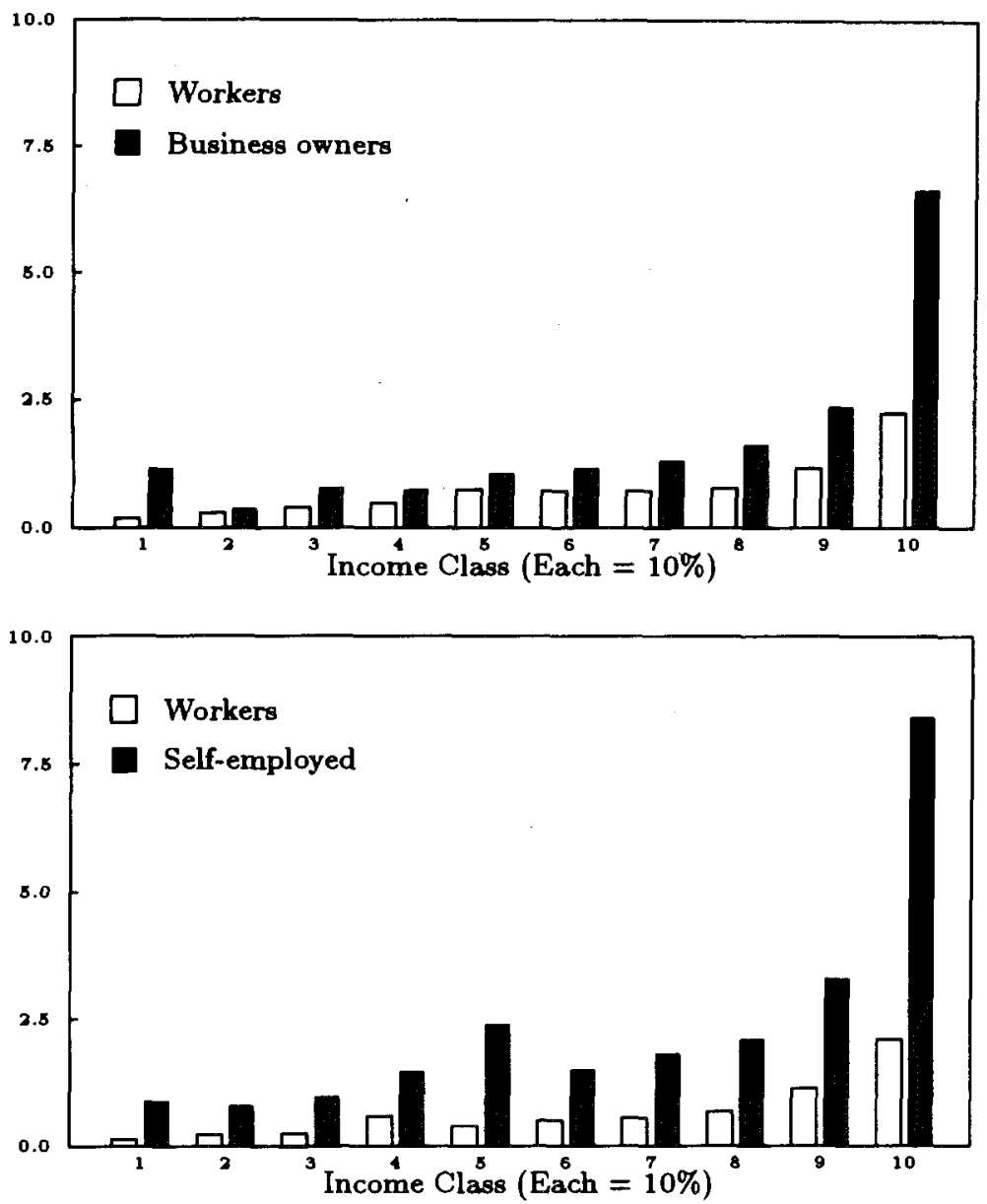

Figure 2. Average Per-Family Wealth of Workers and Business Families in Each Income Decile as Average of 1984 and 1989 PSID Data. The Top Graph Adopts the First Definition of Entrepreneurs while the Bottom Graph Adopts the Second Definition of Entrepreneurs.

of total per-family wealth: the top graph for the first definition of entrepreneurs and the bottom graph for the second definition of entrepreneurs. ${ }^{7}$ The decile thresholds are determined with respect to the total sample, and therefore, worker and business families located in the same income decile dispose, approximately and with the exception of the first and last decile, of the same income. More detailed information is provided by Tables 9 and 10 in the Appendix.

Figure 2 shows that business families own on average higher levels of wealth, relative to their incomes, than worker families. If we consider the total sample of business and worker families, the ratio of wealth to income is more than twice as large as it is for business families. In terms of total distribution, we observe that in 1989, and for the first definition of entrepreneurs, 14.9 percent of all families

\footnotetext{
7"Family income" is defined as the sum of incomes coming from all sources plus transfers of all family members.
} 
are business families; they earn 25 percent of the total income and they own 46 percent of the total wealth. If the second definition of entrepreneurs is adopted, then 17.9 percent of all families are business families; they earn 25 percent of the total income and they own 56 percent of the total wealth. Therefore, there is a concentration of wealth among business families which is not purely explained by the concentration of income among these families.

In order to test the statistical significance of the differences in the ratio of wealth to income of workers and entrepreneurs shown by Figure 2, I estimate a regression equation in which the wealth-to-income ratio is regressed on several variables. Among the regressors I include a constant, a dummy variable taking the value of one for business families, the income of the family, the age of the family head and its square. The age variables are included to capture the dependence of the wealth-income ratio on the life-cycle stage of the family. The estimation is repeated using the two definitions of entrepreneurs and the 1984 and 1989 data. Given the similarity of the results using the 1984 and 1989 data, Sections (a) and (b) of Table 1 only report the results for the 1989 sample. $^{8}$

TABLE 1

WEALTH-TO-INCOME RATIO REgRESSION

\begin{tabular}{|c|c|c|c|c|c|c|c|c|}
\hline & & st. & BusDum & Income & Age & $\mathrm{Age}^{2}$ & Obs. & $R^{2}$ \\
\hline (a) & $\begin{array}{l}\text { PSID data-Business owners } \\
\text { Coefficient } \\
\text { t-Statistic }\end{array}$ & $\begin{array}{l}-1.733 \\
-1.911\end{array}$ & $\begin{array}{c}3.341 \\
10.59\end{array}$ & $\begin{array}{l}0.006 \\
2.626\end{array}$ & $\begin{array}{l}0.073 \\
1.811\end{array}$ & $\begin{array}{l}0.001 \\
1.245\end{array}$ & 5,053 & 0.24 \\
\hline (b) & $\begin{array}{l}\text { PSID data Self-employed } \\
\text { Coefficient } \\
t \text {-Statistic }\end{array}$ & $\begin{array}{l}2.230 \\
1.692\end{array}$ & $\begin{array}{c}4.897 \\
13.99\end{array}$ & $\begin{array}{l}0.005 \\
1.977\end{array}$ & $\begin{array}{l}-0.130 \\
-2.003\end{array}$ & $\begin{array}{l}0.003 \\
3.715\end{array}$ & 3,636 & 0.20 \\
\hline (c) & $\begin{array}{l}\text { SCF data-Business owners } \\
\text { Coefficient } \\
\text { t-Statistic }\end{array}$ & $\begin{array}{l}-4.436 \\
-5.905\end{array}$ & $\begin{array}{l}4.598 \\
16.11\end{array}$ & $\begin{array}{l}-0.002 \\
-4.086\end{array}$ & $\begin{array}{l}0.195 \\
6.242\end{array}$ & $\begin{array}{l}-0.000 \\
-0.966\end{array}$ & 3.857 & 0.17 \\
\hline (d) & $\begin{array}{l}\text { SCF data-Self-employed } \\
\text { Coefficient } \\
\text { t-Statistic }\end{array}$ & $\begin{array}{l}1.776 \\
2.376\end{array}$ & $\begin{array}{c}3.424 \\
17.94\end{array}$ & $\begin{array}{l}-0.001 \\
-1.444\end{array}$ & $\begin{array}{l}-0.100 \\
-2.887\end{array}$ & $\begin{array}{l}0.003 \\
6.833\end{array}$ & 2,771 & 0.18 \\
\hline
\end{tabular}

Note: Regressions (a) and (b) use data from the Panel Study of Income Dynamics for the year 1989; regressions (c) and (d) use data from the Survey of Consumer Finances for the year 1992.

In all regressions the business dummy variable is positive and highly significant. Moreover, the significance of the business dummy does not change using different specifications of the regression equation. In order to show that this result is not only a feature of the PSID data, the same regression equation is estimated using data from the 1989 and 1992 Survey of Consumer Finances adopting similar definitions of family income, wealth and entrepreneurs. Given the similarity of the estimates using the 1989 and the 1992 data, Sections (c) and (d) of Table 1 only report the regression results using the 1992 data. These estimates confirm the statistical significance of the higher wealth to income ratio of business families.

\footnotetext{
${ }^{8}$ The sample does not include families with negative or zero incomes. In order to include these families we have to impute positive values to this variable. One possibility is to assume that the incomes of these families are all equal to one dollar. Extending the sample in this way, however, does not change the general results as demonstrated by the values of the $t$-statistics for the business dummy, which become: (a) 10.26 ; (b) 12.17 ; (c) 6.03 ; (d) 4.94 .
} 


\section{ENTREPRENEURShIP AND Social Mobility}

After analyzing the static aspects of the distribution of wealth between workers and entrepreneurs, this section analyzes its dynamics, that is, the movement of these families inside the distribution or socio-economic mobility. Table 2

TABLE 2

Five-Year Transition Matrices for Net Family Wealth

\begin{tabular}{|c|c|c|c|c|c|c|c|}
\hline & Class I & Class II & Class III & Class I & Class II & Class III & $\chi^{2}$-test \\
\hline & \multicolumn{3}{|c|}{ Staying Workers } & \multicolumn{3}{|c|}{ Switching Workers } & \\
\hline Class I & 0.81 & 0.18 & 0.01 & 0.54 & 0.30 & 0.16 & 100.3 \\
\hline Class II & 0.21 & 0.65 & 0.14 & 0.12 & 0.53 & 0.35 & 34.8 \\
\hline \multirow[t]{2}{*}{ Class III } & 0.02 & $\overline{0.21}$ & $\underline{0.77}$ & 0.00 & $\overline{0.15}$ & $\underline{0.85}$ & 5.1 \\
\hline & \multicolumn{3}{|c|}{ Switching Entrepreneurs } & \multicolumn{3}{|c|}{ Staying Entrepreneurs } & \\
\hline Class I & 0.86 & 0.11 & 0.03 & 0.24 & 0.51 & 0.25 & 34.3 \\
\hline Class II & $\overline{0.23}$ & 0.60 & 0.18 & $\overline{0.20}$ & $\underline{0.38}$ & 0.42 & 13.2 \\
\hline Class III & 0.02 & $\overline{0.22}$ & 0.76 & 0.02 & $\overline{0.09}$ & 0.89 & 14.4 \\
\hline
\end{tabular}

Note: Sample period 1984-89.

reports net wealth transition matrices of four sub-samples of families in the period 1984-89 classified according to the second definition of entrepreneurs (business owners). ${ }^{9,10}$ The first sub-sample, "staying workers," is composed of families that do not own a business in both years 1984 and 1989. The second sub-sample, "switching workers," is composed of families that own a business in 1989 but not in 1984. The third and fourth sub-samples cover the other two cases: "switching entrepreneurs," that is families that own a business in 1984 but not in 1989, and "staying entrepreneurs," that is families that own a business in both the starting and final years. The selected sub-samples have been divided into three classes according to the 1984 family wealth (starting class) and 1989 family wealth (ending class), where the class thresholds are determined by dividing the total sample in three wealth groups, with each group including one third of all families. ${ }^{11}$ Each row of the matrices specifies the class position in 1989 of the families located in the particular 1984 class of wealth.

Looking at the top section of Table 2, which reports the transition matrices for families that at the beginning of the period do not own a business (worker families), we observe:

(i) In the lower class, the percentage of families moving to a higher class is greater for the sub-sample of workers that acquire a business (switching workers) than for the sub-sample of staying workers.

\footnotetext{
${ }^{9}$ These matrices do not take into account changes in family size and composition, which are important sources of family wealth dynamics. However, if we assume that all families have the same probabilities of facing a structural change, these changes should not have any impact in differentiating the income and wealth dynamics of workers and entrepreneurs.

${ }^{10}$ The transition matrices constructed using the second definition of entrepreneurs (self-employed) are very similar to the matrices constructed using the first definition (business owners).

${ }^{11}$ The thresholds for the starting classes are determined using the 1984 wealth data, while the thresholds for the ending classes are determined using the 1989 wealth data. The matrices provide information only on the relative mobility of the families rather than on the absolute changes in the value of wealth.
} 
(ii) In the middle class, for the sub-sample of workers that become entrepreneurs, the percentage of families that are upwardly-mobile is higher than the percentage of downwardly-mobile families. The reverse is observed for staying workers.

(iii) In the upper class, the percentage of families falling to lower classes is smaller for switching workers than for the other worker families.

Looking now at the bottom section of Table 2, which reports data for families that at the beginning of the period own a business (entrepreneurs), we observe:

(i) In the lower class, the percentage of families moving to a higher class is greater for the sub-sample of staying entrepreneurs.

(ii) In the middle class, for the sub-sample of staying entrepreneurs, the percentage of upwardly-mobile families is higher than the percentage of downwardly-mobile families. The reverse is observed for switching entrepreneurs.

(iii) In the upper class, the percentage of families falling to a lower class is smaller for staying entrepreneurs than for switching entrepreneurs.

The observations listed above point out substantial differences in the mobility patterns of workers and entrepreneurs. While worker families (both new and old), tend to stay in or move to lower positions of wealth, both new and old business families tend to stay in or move to higher positions. Therefore, the undertaking of an entrepreneurial activity is an important way through which families switch to higher wealth classes.

In order to test the significance of the differences in wealth mobility between workers and entrepreneurs, the last column of Table 2 reports the value of the $\chi^{2}$ statistic for each starting class of wealth. This statistic tests the null hypothesis that the probability distribution of families across wealth classes is not affected by the switch to or from entrepreneurship. More specifically, it tests whether each row of the transition matrix of staying workers (entrepreneurs) is statistically different from the corresponding row of the transition matrix for switching workers (entrepreneurs). The statistic is distributed as a $\chi^{2}$ with 4 degrees of freedom, and the hypothesis of independence can be rejected at a 5 percent significance level in five cases out of six. ${ }^{12}$

The different wealth mobility may reflect differences in earned incomes. It can be argued, in fact, that the upward mobility experienced by entrepreneurs, as opposed to the downward mobility experienced by workers, is a consequence of higher incomes earned by entrepreneurs. In order to verify this hypothesis, Table 3 reports the transition matrices for the ratio of wealth to income, constructed following the same methodology used in the construction of Table 2 . As shown by this table, business families experience greater upward mobility than worker families, also in the ratio of wealth to income, and therefore, the tendency of business families to be upwardly mobile is not merely a consequence of their higher incomes. ${ }^{13}$

\footnotetext{
${ }^{12}$ The critical value at 5 percent significance level is 9.49 .

${ }^{13}$ For families reporting negative or zero values of incomes, the wealth-to-income ratio is computed by imputing the value of one dollar to their incomes. The alternative is to remove these families from the sample. The results, however, are not affected and the hypothesis of independence is also rejected at a 5 percent significance level in four cases out of six.
} 
TABLE 3

Five-Yeai: Transition Matrices for Family Wealth-Income Ratio

\begin{tabular}{|c|c|c|c|c|c|c|c|}
\hline & Class I & Class II & Class III & Class I & Class II & Class III & $\chi^{2}$-test \\
\hline & \multicolumn{3}{|c|}{ Staying Workers } & \multicolumn{3}{|c|}{ Switching Workers } & \\
\hline Class I & $\underline{0.79}$ & 0.19 & 0.02 & 0.56 & 0.28 & 0.16 & 69.2 \\
\hline Class II & $\overline{0.21}$ & 0.61 & 0.18 & $\overline{0.16}$ & $\underline{0.49}$ & 0.35 & 21.0 \\
\hline \multirow[t]{2}{*}{ Class III } & 0.05 & $\overline{0.21}$ & $\underline{0.74}$ & 0.00 & $\overline{0.31}$ & $\underline{0.69}$ & 9.1 \\
\hline & \multicolumn{3}{|c|}{ Switching Entrepreneurs } & \multicolumn{3}{|c|}{ Staying Entrepreneurs } & \\
\hline Class I & 0.75 & 0.23 & 0.02 & 0.42 & 0.42 & 0.16 & 14.2 \\
\hline Class II & $\overline{0.19}$ & 0.54 & 0.27 & $\overline{0.16}$ & 0.47 & 0.37 & 2.8 \\
\hline Class III & 0.07 & 0.26 & 0.67 & 0.02 & $\overline{0.14}$ & 0.84 & 13.9 \\
\hline
\end{tabular}

Note: Sample period 1984-89.

\section{Testing the Different Wealth-to-Income Ratio of Workers AND ENTREPRENEURS}

The mobility properties shown by Tables 2 and 3 , and the analysis conducted in Section 1 suggest the idea that the accumulation behavior of entrepreneurs differ from the accumulation behavior of workers, with the former accumulating higher levels of wealth relative to income. According to this hypothesis, if we compare workers and business families earning the same income and owning the same level of wealth, the latter should save on average more. Or, said in a different way, entrepreneurs have a higher long-run target in the ratio of wealth to income than workers. It is this difference in saving behavior or wealth-to-income target that contributes to generate higher concentration of wealth.

In order to further investigate this hypothesis, I consider the following dynamic equation:

$$
\Delta k_{i t}=\alpha_{k}\left(k_{i t}-\bar{k}_{i}\right)+\alpha_{y}\left(y_{i t}-\bar{y}_{i}\right)+\varepsilon_{i t}
$$

where $k_{i t}$ and $y_{i t}$ are the logarithm of wealth and income of family $i$ at time $t$ and $\bar{k}_{i}$ and $\bar{y}_{i}$ are the optimal long-run level of wealth and the permanent level of income. The hypothesis underlying this equation is that the change in the value of wealth depends on: (a) how much the current value of wealth diverges from its long run target $\bar{k}_{i}$; (b) how much the current level of income (or temporary income) diverges from its permanent level $\bar{y}_{i}$; and (c) other factors captured by the residual variable $\varepsilon_{i}$. Equation (1) can be rewritten as:

$$
\Delta k_{i t}=-\left(\alpha_{k}+\alpha_{y}\right) \bar{y}_{i}-\alpha_{k}\left(\bar{k}_{i}-\bar{y}_{i}\right)+\alpha_{k} k_{i t}+\alpha_{y} y_{i t}+\varepsilon_{i t} .
$$

In the above equation the term $\bar{k}_{i}-\bar{y}_{i} \equiv \kappa_{i}$ represents the long-run wealth-toincome ratio of family $i$. If we assume that $\kappa_{i}=\phi_{0}+\phi_{1} b_{i}$, where $b_{i}$ is the entrepreneurial propensity of family $i$, then equation (2) can be rewritten as:

$$
\Delta k_{i t}=c+\alpha_{\bar{y}} \bar{y}_{i}+\alpha_{b} b_{i}+\alpha_{k} k_{i t}+\alpha_{y} y_{i t}+\varepsilon_{i t}
$$

where $c=-\alpha_{k} \phi_{0}, \alpha_{\bar{y}}=-\left(\alpha_{k}+\alpha_{y}\right), \alpha_{b}=-\alpha_{k} \phi_{1}$. This equation can be used to test the dependence of the long-run wealth-to-income ratio on the entrepreneurial propensity of the family. 
Before estimating equation (3), we need an estimate of the permanent component of income $\overline{y_{i}}$. The estimation of $\overline{y_{i}}$ is based on the assumption that the current log-level of income is given by the permanent component $\bar{y}_{i}$ plus a transitory and time dependent component $\tilde{y}_{i t}$, that is:

$$
y_{i t}=\bar{y}_{i}+\tilde{y}_{i t} .
$$

The transitory component is in turn decomposed in an age-dependent component - which is approximated with a cubic polynomial in age - and a stochastic element $\eta_{i t}$ which follows a first order autoregressive process. Specifically:

$$
\tilde{y}_{i t}=\psi_{1} A_{i t}+\psi_{2} A_{i t}^{2}+\psi_{3} A_{i t}^{3}+\eta_{i t} \text { with } \eta_{i t}=\rho \eta_{i t-1}+v_{i t}
$$

where $A_{i t}$ denotes the age of the head of family $i$ at time $t$. Using equations (4) and (5) at two different dates, it is possible to express the current log-level of income as:

$$
y_{i t}=c_{i}+\rho y_{i t-1}+\gamma_{1} A_{i t}+\gamma_{2} A_{i t}^{2}+\gamma_{3} A_{i t}^{3}+v_{i t}
$$

where $c_{i}=\psi_{1}+\psi_{2}+\psi_{3}+(1-\rho) \bar{y}_{i} ; \gamma_{1}=(1-\rho) \psi_{1}+2 \psi_{2}+3 \psi_{3} ; \gamma_{2}=(1-\rho) \psi_{2}+3 \psi_{3}$; $\gamma_{3}=(1-\rho) \psi_{3}$.

Equation (6) is a fixed effect regression model which is estimated on the PSID sample composed of families interviewed in all years from 1980 through 1993. Therefore, the estimation uses the fourteen observations of family incomes from 1979 through 1992. The estimation results are reported in Table 4.

\begin{tabular}{|c|c|c|c|c|c|c|c|}
\hline & & $y_{i t-1}$ & $A_{i t}$ & $A_{i t}^{2}$ & $A_{i t}^{3}$ & Obs. & $R^{2}$ \\
\hline (a) & $\begin{array}{l}\text { Business owners } \\
\text { Coefficient } \\
\text { t-Statistic }\end{array}$ & $\begin{array}{r}0.424 \\
82.231\end{array}$ & $\begin{array}{l}12.753 \\
20.792\end{array}$ & $\begin{array}{l}-19.80 \\
-17.67\end{array}$ & $\begin{array}{r}8.929 \\
13.801\end{array}$ & 2,740 & 0.24 \\
\hline (b) & $\begin{array}{l}\text { Self-employed } \\
\text { Coefficient } \\
t \text {-Statistic }\end{array}$ & $\begin{array}{r}0.437 \\
62.702\end{array}$ & $\begin{array}{l}4.743 \\
4.165\end{array}$ & $\begin{array}{l}-3.274 \\
-1.354\end{array}$ & $\begin{array}{l}-1.142 \\
-0.686\end{array}$ & 1,436 & 0.27 \\
\hline
\end{tabular}

TABLE 4

Fixed EFFect Estimation of Equation (6)

Note: $y_{i t-1}: \log$-value of family income at time $t-1$ at 1979 prices. $A_{i t}$ : age of the head of the family at time $t$ divided by 100 .

The estimates of the fixed effect $c_{i}$ are then used to derive estimates of the permanent component of income $\bar{y}_{i}$ in the estimation of equation (3). Several specifications of equation (3) are estimated using data from the same sample of families used to estimate equation (6) and the results are reported in Table 5. ${ }^{14}$

The results reported in sections (a.1) and (b.1) of Table 5 are for the basic formulation of equation (3). In these two regressions the business propensity of the family is measured by the number of years in which the family has been in

\footnotetext{
${ }^{14}$ Since the model is specified in log-levels and the logarithm is defined only for positive values, families reporting negative or zero income and wealth in at least one year during the period 1979-92, are eliminated from the sample. Equation (3) is also estimated on the full sample by imputing the value of one dollar to income and wealth when they take negative or zero values. The significance of the business variable(s), however, is not affected.
} 
TABLE 5

Estimation of Equation (3). Dependent Variable $\Delta k_{i t}$

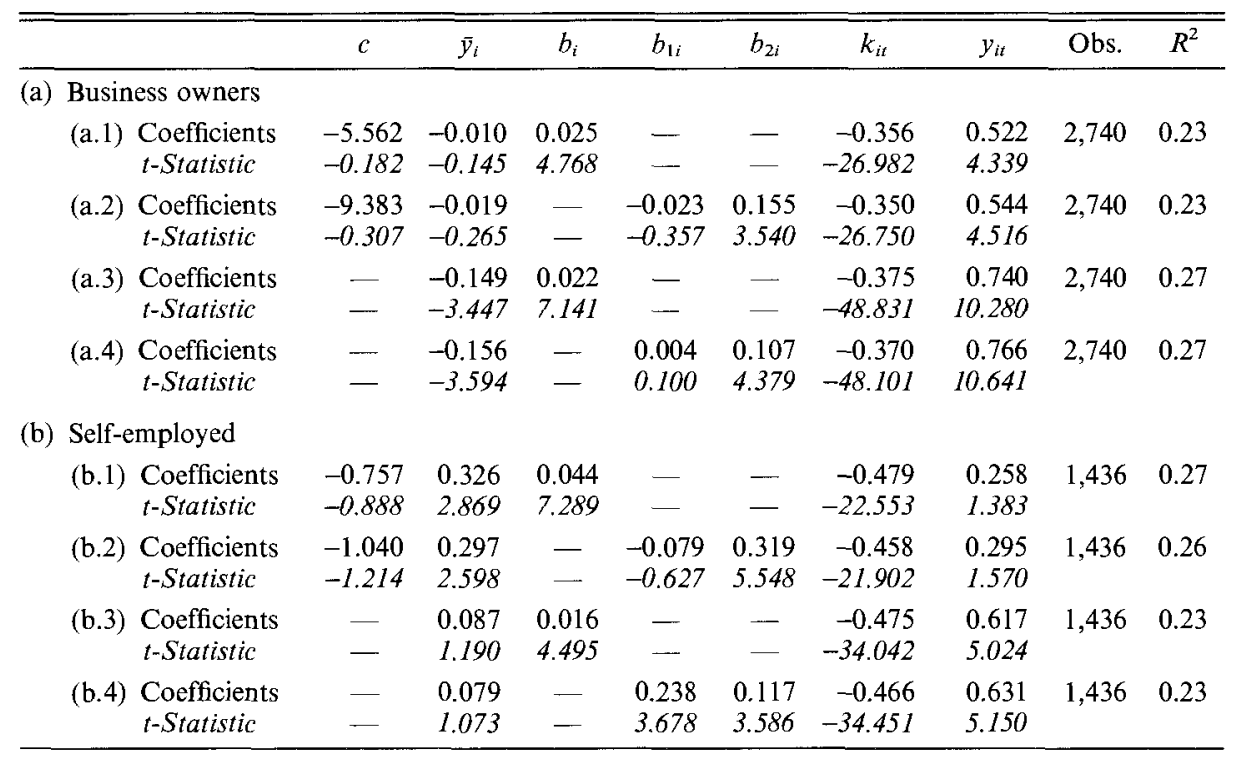

Note: $k_{i t}, k_{i t+1}: \log$-values of 1984 and 1989 family wealth at 1979 prices. $\bar{y}_{i}:$ fix effect estimates of equation (6). $b_{i}$ : number of years in entrepreneurship during the period 1980-92, $b_{1 i}$ : dummy for families with one year of entrepreneurial experience during the period 1980-92. $b_{1 i}$ : dummy for families with more than one year of entrepreneurial experience during the period 1980-92. $y_{i t}: \log$-sum of 1984 through 1988 family incomes at 1979 prices divided by 5 .

the business group during the sample period 1980-92. All the coefficient estimates have the expected size - with $\alpha_{b}$ and $\alpha_{y}$ greater than zero and $\alpha_{k}$ smaller than zero-and they are statistically significant at the 5 percent level. The only exception is the coefficient for income in regression (b.1), which however becomes significant at the 10 percent level. Of particular interest is the coefficient estimates for the business variable $b_{i}$ which is equal to $-\alpha_{k} \phi_{1}$. Given the negative sign of $\alpha_{k}$, the positive sign of this parameter implies a positive value of $\phi_{1}$, and therefore, a higher long-run wealth-to-income ratio of families with higher entrepreneurial propensity. Hence, the result of the regression exercise supports the hypothesis that business families have a higher long-run wealth-to-income ratio than worker families.

Regressions (a.2) and (b.2) replace the entrepreneurial propensity variable used in (a.1) and (b.1) with two dummies. The first dummy takes the value of one for those families that have been in the business group for only one year during the sample period; the second dummy takes the value of one for those families that have been in the business group for more than one year. Only the second dummy is statistically significant, suggesting the existence of non-linearities in the impact of the entrepreneurial propensity of the family on its long-run wealth-to-income ratio. The sign and significance of the other key variables do not change. 
In order to separate out family dynastic effects, I re-estimate a new version of equation (3) extended to include dynasty-specific dummies. The number of dummies added to the equation is equal to the number of 1968 families from which the current sample originates. Therefore, each dummy identifies a particular dynasty. As can been seen from the results of regressions (a.3)-(a.4) and (b.3)(b.4), the dynasty-specific dummies do not affect the basic results obtained in the previous estimations. The only relevant difference is that in regression (b.4) the dummy variable $b_{1 i}$ is now statistically significant. ${ }^{15}$

\section{Entrepreneurial Persistence and Turnover}

The analysis conducted thus far supports the hypothesis that the household's saving behavior changes with the current and future prospect of being an entrepreneur. As a consequence of the different saving behavior, business families accumulate more wealth than worker families and rapidly move to higher wealth classes (upward mobility). In that way, the higher saving behavior of entrepreneurs contributes to generate more concentration of wealth. In these dynamics, an important role is played by entrepreneurial persistence and duration: the longer the business life is, the greater the wealth accumulated by a restricted group of business families, which in turn generates greater concentration in the whole distribution of wealth.

One way of looking at entrepreneurial persistence is to look at the exit and entrance rates from and to entrepreneurship. However, these are only general indicators and, in several respects, incomplete. In fact, it is not only important to look at the entrance and exit rates, but also at the turnover rates of families in the business group. As an extreme example, suppose that in each period ten percent of all families are entrepreneurs but, in the next period, they are all replaced by a different group of families. Moreover, assume that it is always the same two groups of families, both counting ten percent of the population, that alternate in each period. In this example, despite the 100 percent exit rate from entrepreneurship, the turnover of families in the business group is low and the entrepreneurial persistence is high. Hence, the exit and entrance rates are good indicators of business persistence, only if all families face the same probability of engaging in entrepreneurial activities- or in this example, only if all families were to alternate into the position of entrepreneur. However, there are reasons which may prevent this from occurring. Experience is certainly an important aspect of entrepreneurship, due to the existence of learning processes through which successful entrepreneurs improve their ability, as theorized in Hopenhayn (1992), or improve the knowledge of their ability, as in Jovanovic (1982). This implies that the longer the entrepreneurial tenure is, the higher the expected duration.

\footnotetext{
${ }^{15}$ The regression estimations discussed above do not take into consideration the parameter restriction $\alpha_{g}=-\left(\alpha_{k}+\alpha_{y}\right)$, implicit in the derivation of equation (3). However, the imposition of this restriction does not change the basic results.
} 
The top section of Table 6 reports the average annual exit rates from entrepreneurship for the whole sample of business families and for three sub-samples: families with one year of business tenure, families with two years of business tenure, and families with three or more years of business tenure. The table distinguishes between the two definitions of entrepreneurs specified before and the numbers reported are averages over the sample period 1973 through $1992 .^{16}$ As can be seen from the table, the exit rate is high for new entrants (one year of business tenure) but declines quickly for surviving entrepreneurs.

TABLE 6

Exit Rates From Entrepreneurship (Top Section) and Entrance Rates To ENTREPRENEURSHIP (BOTTOM SECTION)

\begin{tabular}{lcr}
\hline \hline & Exit Rate & No. of families \\
\hline (a) Business owners & & \\
All business families & 24.2 & 522 \\
With one year of entrepreneurial tenure & 44.7 & 151 \\
With two years of entrepreneurial tenure & 30.8 & 80 \\
With three or more years of entrepreneurial tenure & 13.4 & 291 \\
(b) Self-employed & & \\
All business families & 13.6 & 384 \\
With one year of entrepreneurial tenure & 35.2 & 75 \\
With two years of entrepreneurial tenure & 19.1 & 48 \\
With three or more years of entrepreneurial tenure & 7.2 & 261 \\
\hline & Entrance Rate & No. of families \\
\hline Business owners & & \\
All worker families & 3.7 & 4,722 \\
Without entrepreneurial experience & 2.6 & 4,506 \\
With entrepreneurial experience & 23.1 & 216 \\
(b) Self-employed & & \\
All worker families & 2.9 & 2,837 \\
Without entrepreneurial experience & 2.0 & 2,556 \\
With entrepreneurial experience & 27.2 & 281 \\
\hline
\end{tabular}

Note: Annual values averaged over the sample period 1973-92. The number of families is the average sample size in each year, from 1973 through 1992.

Experience also plays an important role in affecting the probability of entering entrepreneurship. The bottom section of Table 6 reports the entrance rates to entrepreneurship for the sample of all worker families and for two subsamples: worker families without business experience in all three years prior to initiating an entrepreneurial activity, and worker families which engaged in an entrepreneurial activity during at least one of these years. As for the exit rates,

\footnotetext{
${ }^{16}$ The procedure followed to compute these rates is as follows: Suppose we want to determine the exit rate in 1973. First I select families that are business families in 1972 from the sample of families interviewed in all years from 1970 through 1973 and headed by the same person. The subsample of families with one year of business tenure, then, is the sub-group of families that was not in the business group in 1971. The sub-sample of families with two years of business tenure is given by those families that were in the business group in 1971 but not in 1970 . Finally, the sub-sample of families with three or more years of business tenure is given by those families that were in the business group in both years 1970 and in 1971 (other than in 1972).
} 
the numbers reported are annual averages over the sample period 1973 through $1992 .{ }^{17}$

The analysis of Table 6 reveals that, despite the high exit rates from entrepreneurship for the total sample of entrepreneurs, there is a sub-group of families - those with entrepreneurial experience-that face low probability of exiting and high probability of re-entering. Consequently, the turnover in the business group is low and the entrepreneurial persistence high. It is this persistence that allows a restricted group of business families to accumulate higher levels of wealth relative to workers which, in turn, generates higher concentration of wealth.

Two hypotheses can be proposed to explain the low turnover of families in the business group. The first hypothesis is related to business experience. Even if the termination of an entrepreneurial activity is usually dictated by poor performance, the acquisition of entrepreneurial skills does not depend entirely on the success or failure of the business undertaken. Furthermore, the experience gained is not immediately lost after terminating the business. The second hypothesis is related to the existence of borrowing constraints. Financial constraints select entrepreneurs among richer families, while at the same time, richer families are those which engaged in business activities in previous periods. Since the wealth accumulated during the business period is not immediately depleted, these families have greater resources to restart a business.

In order to analyze the importance of these two hypothesis-namely, the existence of a learning process in the ability to manage a business, and the existence of borrowing constraints - I estimate a probit model in which the probability to enter entrepreneurship is related to several variables. The existence of a learning process is captured by three dummy variables: the first dummy takes the value of one for families that were entrepreneurs three years before the entrance to entrepreneurship; the second dummy takes the value of one for families that were entrepreneurs two years before the entrance (but not three years before); the third dummy takes the value of one for families that were in the business group two and three years before the entrance to entrepreneurship. The importance of borrowing constraints or other financial factors is captured by the variable family's wealth. The entrance probability also depends on two dummy variables capturing the educational achievement of the head of the family-one for high school diploma and one for college degree and on a cubic polynomial in the age of the head. The estimation is repeated for the two definitions of entrepreneurs and for the years 1985 and 1990 . Given the similarity of the estimation results for the two years, Table 7 only reports the estimates for $1990 .^{18}$

\footnotetext{
${ }^{17}$ The procedure followed to determine these rates is the following: Suppose we want to determine the entrance rate in 1973. First I select families that are not business families in 1972 from the sample of families interviewed in all years from 1970 through 1973 and headed by the same person. The subsample of inexperienced families, then, is given by the sub-group of families that were not in the business group in 1970 and 1971. The experienced entrants, instead, are the sub-group of families that in 1970 and/or 1971 were in the business group.

${ }^{18}$ In each estimation the sample is composed of families interviewed in all relevant years and headed by the same person.
} 
TABLE 7

Probit Estimation of ENTERING ENTrepreneurship in THE Year 1990

\begin{tabular}{lccr}
\hline \hline Variable & Coefficient & Std. Error & $t$-Stat \\
\hline (a) First definition of entrepreneurs & (business owners) & & \\
Constant & 0.552 & 1.188 & 0.465 \\
ExpDum1 & 0.686 & 0.135 & 5.091 \\
ExpDum2 & 0.809 & 0.183 & 4.430 \\
ExpDum3 & 1.444 & 0.134 & 10.740 \\
Wealth & 0.774 & 0.327 & 2.369 \\
Wealth & 0.055 & 0.183 & 0.298 \\
High School & 0.051 & 0.097 & 0.530 \\
College Degree & 0.040 & 0.117 & 0.349 \\
Age $^{2}$ & -1.440 & 0.801 & -1.797 \\
Age $^{3}$ & 0.281 & 0.170 & 1.653 \\
Age $^{3}$ & -0.020 & 0.011 & -1.718
\end{tabular}

Observations $=4,872$

Likelihood ratio $=191.41$

(b) Second definition of entrepreneurs (self-employed)

$\begin{array}{lrrr}\text { Constant } & -2.548 & 1.859 & -1.371 \\ \text { ExpDum1 } & 1.026 & 0.270 & 3.799 \\ \text { ExpDum2 } & 1.045 & 0.274 & 3.814 \\ \text { ExpDum3 } & 1.522 & 0.237 & 6.413 \\ \text { Wealth } & 0.187 & 0.059 & 3.151 \\ \text { Wealth } & -0.969 & 0.521 & -1.859 \\ \text { High School } & 0.228 & 0.185 & 1.234 \\ \text { College Degree } & 0.100 & 0.208 & 0.480 \\ \text { Age } & 0.472 & 1.189 & 0.397 \\ \text { Age }^{2} & -0.181 & 0.242 & -0.749 \\ \text { Age }^{3} & 0.017 & 0.016 & 1.102\end{array}$

Observations $=2,874$

Likelihood ratio $=57.74$

Note: ExpDum1: business families in 1987 but not in 1988. ExpDum2: business families in 1988 but not in 1987. ExpDum3: business families in 1987 and 1988 . Wealth: 1989 family wealth divided by $1,000,000$. Age: age of the head of the family divided by 10 .

The first important result is relative to the coefficient estimates for the experience dummies. All three variables have a positive and significant effect on the probability of entering entrepreneurship. Moreover, it is interesting to note that the coefficient estimate for the first variable is smaller than the estimate for the second variable which, in turn, is smaller than the coefficient estimate for the third variable. If we interpret the positive effect of business experience as a consequence of a learning process in the ability to manage a business, then this result reveals two important facts. First, the learned ability is subject to depreciation. This is because the effect of old experiences (first dummy variable) on the probability of entering entrepreneurship is smaller than the effect of recent experiences (second dummy variable). Second, the ability to manage a business is accumulated along time (learning by doing). This is because the coefficient estimates for the third dummy variable, that is for families with two years of business experience, is greater than for the other two dummy variables, that is for families with only one year of business experience. The second important result is that the value of 
wealth has a positive and significant coefficient - even after controlling for business experience-which supports the hypothesis of the existence of borrowing constraints.

The educational attainment of the head of the family is positive but not significantly different from zero and therefore the level of education does not seem to have an influence on the probability to enter entrepreneurship. Similarly for the age of the head: the coefficient estimates are not different from zero at a 5 percent significant level. This result may seem at odds with the observation that in lower age classes the fraction of entrepreneurs is smaller. However, the result of the probit estimation suggests that the smaller fraction of entrepreneurs in younger families is the consequence of the lower asset holdings and experience of these families.

A similar model is also estimated for the exit probability. The model considers the same explanatory variables considered in the entrance model with the exception of the experience dummies. The three experience dummies of the previous model have now been replaced by two dummy variables: the first variable assumes a value of one for business families with one year of business experience and the second for families with two or more years of business experience. The estimation results are presented in Table 8 and they parallel the results previously obtained in the estimation of the entrance probability. It is important to point out the negative effect of experience that confirms the existence of a learning process that reduces the probability of exiting from entrepreneurship. The effect of wealth is to reduce the probability of exit: the sign of the coefficient estimation for wealth (the linear component) is negative even though significant only for the first definition of entrepreneurs. The other variables, that is, education and age, are not statistically significant.

In summary, the estimation results of the probability model presented in Table 7 point out the importance of two factors in explaining the entrance rate to entrepreneurship: the asset holdings of the household and its experience. At the same time the results reported in Table 8 show that the same factors have a positive effect on the probability of remaining an entrepreneur. These two factors explain the high persistence and low turnover of business families which, associated with their higher saving rates, constitutes an important mechanism allowing the concentration of assets in the hands of entrepreneurs, and generates a more unequal distribution of wealth.

\section{Conclusion}

The object of this paper is to study the importance of entrepreneurship for wealth concentration and mobility using data from the Panel Study of Income Dynamics. The analysis shows a significant concentration of wealth within enterprising households which, at least in part, is responsible for the high concentration of wealth observed in the data. The higher saving rates of entrepreneurs could be one of the explanations for this concentration and the statistical test conducted in Section 3 is supportive of the hypothesis that entrepreneurs have higher saving rates than workers. Consequently, the study of the different accumulation behavior of workers and entrepreneurs represents an important step toward the understanding of wealth concentration and inequality. 
TABLE 8

Probit Estimation of Exiting Entrepreneurship in the Year 1990

\begin{tabular}{lccr}
\hline \hline Variable & Coefficient & Std. Error & $t$-Stat \\
\hline (a) First definition of entrepreneurs (business owners) & & \\
Constant & 0.058 & 2.365 & 0.024 \\
ExpDum1 & -0.155 & 0.173 & -0.893 \\
ExpDum2 & -0.991 & 0.130 & -7.634 \\
Wealth & -0.432 & 0.188 & -2.298 \\
Wealth & 0.004 & 0.002 & 1.757 \\
High School & -0.032 & 0.187 & -0.173 \\
College Degree & -0.098 & 0.203 & -0.485 \\
Age & 0.140 & 1.491 & 0.093 \\
Age $^{2}$ & -0.072 & 0.298 & -0.240 \\
Age $^{3}$ & 0.007 & 0.019 & 0.363
\end{tabular}

Observations $=723$

Likelihood ratio $=115.63$

(b) Second definition of entrepreneurs (self-employed)

$\begin{array}{lrrr}\text { Constant } & 4.860 & 3.857 & 1.260 \\ \text { ExpDum1 } & -0.429 & 0.287 & -1.497 \\ \text { ExpDum2 } & -0.755 & 0.200 & -3.783 \\ \text { Wealth } & -0.245 & 0.191 & -1.283 \\ \text { Wealth } & 0.003 & 0.004 & 0.650 \\ \text { High School } & 0.063 & 0.254 & 0.247 \\ \text { College Degree } & 0.263 & 0.268 & 0.981 \\ \text { Age } & -3.779 & 2.603 & -1.459 \\ \text { Age }^{2} & 0.873 & 0.563 & 1.487 \\ \text { Age }^{3} & -0.059 & 0.039 & -1.513\end{array}$

Observations $=494$

Likelihood ratio $=29.00$

Note: ExpDum1: business families in 1988 but not in 1987. ExpDum2: business families in 1988 and 1987 . Wealth: 1989 family wealth divided by 1,000,000. Age: age of the head of the family divided by 10 .

The importance of entrepreneurship for wealth concentration - through the different accumulation behavior of workers and entrepreneurs-depends on the turnover rate and persistence of families in the business group. Due to the low turnover in the business group, business families spend a long time with the ownership of a business during which they accumulate consistent amounts of wealth, and this generates higher concentration of wealth.

The paper also analyzes socio-economic mobility and shows that workers and entrepreneurs experience different mobility properties, with the former tending to stay or move to lower wealth classes and the latter to stay or move to higher wealth classes. Therefore, the undertaking of an entrepreneurial activity increases the household's probability of moving to a higher wealth class and the mobility properties of the whole society depend on the breadth and ease of access to business activities. However, the low turnover of enterprising families - due to the existence of borrowing constraints and/or to the existence of processes of learning - limits the accessibility of the business activity to a restricted group of families.

The analysis of social mobility has relevant policy implications for governments wishing to alter existing patterns of socio-economic mobility which, however, is beyond the purpose of this paper. 
TABLE 9

Income and Wealth Distribution Averages Based on the First Definition of Entrepreneurs (Business Owners)

\begin{tabular}{|c|c|c|c|c|c|c|}
\hline & \multicolumn{3}{|c|}{ Workers } & \multicolumn{3}{|c|}{ Entrepreneurs } \\
\hline & Percent & Income & Wealth & Percent & Income & Wealth \\
\hline \multicolumn{7}{|c|}{ (a) 1984 PSID data } \\
\hline Decile 1 & 9.4 & 3,739 & 20,962 & 0.5 & $-19,653$ & 83,095 \\
\hline Decile 2 & 9.5 & 9,185 & 29,065 & 0.5 & 9,323 & 53,559 \\
\hline Decile 3 & 9.2 & 13,890 & 43,200 & 0.8 & 14,300 & 64,772 \\
\hline Decile 4 & 9.0 & 18,736 & 47,865 & 1.0 & 18,673 & 78,602 \\
\hline Decile 5 & 9.1 & 23,658 & 93,264 & 0.9 & 23,847 & 125,254 \\
\hline Decile 6 & 8.8 & 28,916 & 80,689 & 1.2 & 29,045 & 133,246 \\
\hline Decile 7 & 8.6 & 34,645 & 77,770 & 1.4 & 34,678 & 139,807 \\
\hline Decile 8 & 8.2 & 41,737 & 79,552 & 1.7 & 41,720 & 188,605 \\
\hline Decile 9 & 7.8 & 52,261 & 113,962 & 2.2 & 53,159 & 235,878 \\
\hline Decile 10 & 6.2 & 83,411 & 240,543 & 3.8 & 115,906 & 533,508 \\
\hline Total & 85.9 & 28,610 & 76,515 & 14.1 & 53,890 & 251,735 \\
\hline \multicolumn{7}{|c|}{ (b) 1989 PSID data } \\
\hline Decile 1 & 9.6 & 4,848 & 17,476 & 0.3 & $-6,876$ & 240,091 \\
\hline Decile 2 & 9.6 & 10,197 & 43,512 & 0.5 & 11,251 & 30,241 \\
\hline Decile 3 & 9.3 & 16,381 & 55,176 & 0.7 & 16,873 & 143,362 \\
\hline Decile 4 & 8.9 & 22,600 & 76,462 & 1.2 & 22,672 & 108,653 \\
\hline Decile 5 & 8.7 & 28,578 & 88,870 & 1.2 & 28,704 & 138,094 \\
\hline Decile 6 & 8.6 & 35,168 & 98,378 & 1.4 & 35,776 & 163,320 \\
\hline Decile 7 & 8.7 & 43,049 & 102,318 & 1.3 & 43,211 & 197,054 \\
\hline Decile 8 & 8.0 & 53,084 & 116,511 & 2.0 & 52,664 & 219,134 \\
\hline Decile 9 & 7.7 & 67,434 & 189,626 & 2.3 & 67,688 & 384,083 \\
\hline Decile 10 & 6.0 & 116,356 & 338,844 & 4.0 & 150,442 & $1,301,010$ \\
\hline Total & 85.1 & 35,940 & 102,414 & 14.9 & 70,160 & 503,971 \\
\hline
\end{tabular}

Note: Decile thresholds based on Total Family Money Income.

TABLE 10

Income and Wealth Distribution Averages Based on the Second Definition of Entrepreneurs (Self-Employed)

\begin{tabular}{|c|c|c|c|c|c|c|}
\hline & \multicolumn{3}{|c|}{ Workers } & \multicolumn{3}{|c|}{ Entrepreneurs } \\
\hline & Percent & Income & Wealth & Percent & Income & Wealth \\
\hline \multicolumn{7}{|c|}{ (a) 1984 PSID data } \\
\hline Decile 1 & 8.5 & 8,542 & 10,243 & 1.9 & $-5,489$ & 98,115 \\
\hline Decile 2 & 8.3 & 14,564 & 19,387 & 1.3 & 14,464 & 115,868 \\
\hline Decile 3 & 8.9 & 19,637 & 23,823 & 1.0 & 19,763 & 113,796 \\
\hline Decile 4 & 9.2 & 24,394 & 88,077 & 0.8 & 24,649 & 179,020 \\
\hline Decile 5 & 9.0 & 29,154 & 42,075 & 1.0 & 29,234 & 361,668 \\
\hline Decile 6 & 8.9 & 34,253 & 57,778 & 1.0 & 33,568 & 155,762 \\
\hline Decile 7 & 9.0 & 39,870 & 61,904 & 1.2 & 40,511 & 250,532 \\
\hline Decile 8 & 8.6 & 47,039 & 72,756 & 1.4 & 47,592 & 196,638 \\
\hline Decile 9 & 8.3 & 58,228 & 128,408 & 1.5 & 59,678 & 374,484 \\
\hline Decile 10 & 7.0 & 90,212 & 210,720 & 3.0 & 136,767 & 705,361 \\
\hline Total & 85.8 & 35,473 & 68,754 & 14.2 & 51,086 & 307,921 \\
\hline \multicolumn{7}{|c|}{ (b) 1989 PSID data } \\
\hline Decile 1 & 8.2 & 9,611 & 20,810 & 1.7 & 4,549 & 139,916 \\
\hline Decile 2 & 8.3 & 18,442 & 38,212 & 1.7 & 18,739 & 82,359 \\
\hline Decile 3 & 8.7 & 25,014 & 38,071 & 1.3 & 25,108 & 145,096 \\
\hline Decile 4 & 8.7 & 30,889 & 52,508 & 1.2 & 30,941 & 210,203 \\
\hline Decile 5 & 8.5 & 37,203 & 60,312 & 1.6 & 36,720 & 227,838 \\
\hline Decile 6 & 9.0 & 43,752 & 70,949 & 1.3 & 43,781 & 260,006 \\
\hline Decile 7 & 8.2 & 50,967 & 82,125 & 1.5 & 51,151 & 209,569 \\
\hline Decile 8 & 8.0 & 60,990 & 108,649 & 2.0 & 61,428 & 405,976 \\
\hline Decile 9 & 8.0 & 77,856 & 173,848 & 2.0 & 78,624 & 527,635 \\
\hline Decile 10 & 6.4 & 128,936 & 381,755 & 3.6 & 182,782 & $1,785,796$ \\
\hline Total & 82.1 & 46,139 & 95,228 & 17.9 & 69,111 & 565,240 \\
\hline
\end{tabular}

Note: Decile thresholds based on Total Family Money Income. 


\section{A. Data Appendix}

This appendix provides data on the average asset holdings of worker and business families, sorted in ten income groups, as well as the percentage of workers and entrepreneurs in each income group. Table 9 adopts the first definition of entrepreneurs which is based on the family ownership of a business. Table 10 adopts the second definition of entrepreneurs which is based on the main occupation of the head of the family (self-employed as opposed to dependent worker).

\section{REFERENCES}

Behrman, J. R. and P. Taubman, The Intergenerational Correlation Between Children's Adult Earnings and Their Parents' Income: Results from The Michigan Panel Survey of Income Dynamics, The Review of Income and Wealth, 36, 115-27, June, 1990.

Duncan, G. J. and J. N. Morgan, An Overview of Family Economic Mobility, in Duncan, G. J. et al., Years of Poverty, Years of Plenty, Institute for Social Research, University of Michigan, Ann Arbor, 1984.

Evans, D. S. and B. Jovanovic, An Estimated Model of Entrepreneurial Choice under Liquidity Constraints, Journal of Political Economy, 97, 808-27, August, 1989.

and L. S. Leighton, Some Empirical Aspects of Entrepreneurship, American Economic Review, 79, 519-35, June, 1989.

Holtz-Eakin, D., D. Joulfaian, and H. S. Rosen, Sticking it Out: Entrepreneurial Survival and Liquidity Constraints, Journal of Political Economy, 102, 53-75, October, 1994.

Hopenhayn, H., Entry, Exit, and Firm Dynamics in Long Run Equilibrium, Econometrica, 60, 1127 50, September, 1992.

Hungerford, T. L., U.S. Income Mobility in The Seventies and Eighties, The Review of Income and Wealth, 39, 403-17, December, 1993.

Jovanovic, B., The Selection and Evolution of Industry, Econometrica, 50, 649-70, May, 1982.

Quadrini, V. and J. V. Ríos-Rull, Understanding the U.S. Distribution of Wealth, Quarterly Review of The Federal Reserve Bank of Minneapolis, 21, 22-36, Spring, 1997.

Sawhill, I. V. and M. Condon, Is U.S. Income Inequality Really Growing? Policy Bites, The Urban Institute, No. 13, 1992.

Solon, G. R., Intergenerational Income Mobility in The United States, American Economic Review, 82, 393-408, June, 1992.

Wolff, E. N., Changing Inequality of Wealth, American Economic Review, 82, 231-57, May, 1992. , Top Heavy-A Study of The Increasing Inequality of Wealth in America, The Free Press, New York, 1995.

Zimmerman, D. J., Regression Toward Mediocrity in Economic Stature, American Economic Review, $82,409-29$, June, 1992. 